\title{
The Effectiveness of Cyber Counseling Service to Enhance Student Performance in Statistics
}

\author{
Lucia Hernawati $^{1}$, DYP Sugiarto ${ }^{2}$, Edy Purwanto ${ }^{3}$, Awalya $^{4}$ \\ ${ }^{1}$ Doctoral Program of Guidance and Counseling. \\ ${ }^{2,3,4}$ Graduate School Universitas Negeri Semarang \\ ${ }^{1}$ Correspondening email: herna@unika.ac.id
}

\begin{abstract}
Statistics is one of the subjects which is considered difficult by students. The lecturers should not only explain and give exercises to students but also need to listen to what the students feel and think as well as trying to find the solutions they have in statistics class. This study aims to determine the effectiveness of cyber counseling services in improving students skills in statistics and to increase psychological well being. Thirty college students who were attending statistics class and got low scores were involved in this study. Treatment in the form of cyber counseling service was given for four months with a frequency of three hours per day by a lecturer. Students were given an opportunity to share their difficulties and together with their lecturer attempted to find the solution. After the treatment, the monitoring of performance acquisition was done. $T$ test analysis was applied to compare the acquisition performance before and after the assignment was administered. The results show that there was significant difference in the students statistics performance. They improved statistics performance significantly after they received cyber counseling service. These findings are very useful in pursuing appropriate statistical teaching methods for students in college.
\end{abstract}

Keywords: cyber counseling, statistics, psychological well being, college students

\section{Introduction}

Statistics is a required subject of study in many academic disciplines, including in psychology faculty, that causes problems for many students (Nguyen, Newby \& Skordi, 2015). In Psychology faculty Soegijapranata Catholic University - Semarang City Indonesia, the students are set to take the statistic course of 3 credits. In general, based on interviews and observations on students taking statistics subject, it is reported that students did not like statistics subject and felt that the subject is difficult to be learned. It is known that $50 \%$ of the students in the classroom have a below-average performance in statistics course. This is in line with $\mathrm{Tu} \&$ Snyder (2017) stated that students learning statistics felt intimidated with numbers related to unreal possibilities, and were not motivated to struggle learning statistics due to the thought of learning statistics is pointless. Malik (2015) in his research, further found that students experienced unfamiliar feelings when learning statistics materials. The students felt pressured on tests because of expecting getting high grade, and the necessity of expressing logical opinions in front of their lecturers and classmates. Due to these reasons, students became uncomfortable and felt anxious when learning this subject. Riff (2014) mentioned this situation of learning statistics as students condition with low psychological well-being.

In general, the delivery of statistics course material begins with the explanation of the lecturer followed by the application of the theory that has been submitted. However, lecturers often found it difficult to teach statistics, especially in stimulating students participation in the classroom, due to seeking a balance between theory and the theory application, and delivering statistical lectures in the form of abstract concepts (Gningue, Peach, \& Schroder, 2013).

Prior research conducted by (Vinluan 2011, Gokhale \& Bhakare, 2011) found that by making web-based instruction which includes uploading course material on the web to be accessed by students not present during lecture, and giving students opportunity to discuss the subject which have not yet been understood by the students in addition to giving the course in classes, has improved the performance of the students. This web-based instruction really helps introvert students, who were ashamed to ask for questions in class, as they now have a media to get further explanation outside the class hour. But another research conducted by Jung (2011) found that web-based instruction learning model no sinificant differences in increasing academic performance. 
The teacher must find learning model to increase students' statistical performance. The cyber counseling service can be an alternative to helping student to increase statistics performance (Corey, 2013). In this research a web-based facility chat, e-mail, and uploaded course materials are prepared. With this, lecturers in addition to explaining the course material, can also provide cyber counselling services. The service enables lecturers give the students an opportunity to get further explanations or re-explanation on the materials explained in the classroom, in addition to give solutions to problems the students have in understanding the materials. The service is expected to help increase students' interest and increase the intrinsic motivation in studying statistics. Thus, in the end, the overall students' performance in statistics can be increased.

Bloom (2014) stated that cyber counseling services can fulfill four things that must be provided in general counseling services, they include the therapeutic relationship, cognitive insight, affective experience, appropriate client expectations.

Cyber counseling services are possible to be given to college students. Currently students have smartphones, in general. Lots of them even have laptops, tablets, in addition to smartphones. All three have the capability to access internet at affordable internet costs coupled with provisions of public Wi-Fi in public places such as found in the campus, offices, cafés, restaurants, it is possible to proceed cyber counseling services (Joel \& Amanda, 2013).

One thing that can never be apart from the daily life of students is smartphone. It is in line with an anecdote of "far from sight, close to space". Although in far distance, the smartphones enable them to communicate closely with friends via social media such as Facebook, WhatsApp, and Blackberry Messenger. For example, people can post their insecurities in social media, then their friends can give support and empathy wherever they are. These kinds of response can help induce comfort. Usually, the situation of giving empathy and support can be beneficial one way or another (Joel \& Amanda, 2013). Unconsciously, through smartphones the counselees would have a peer counseling services in their own virtual world. This phenomenon has become part of everyday life of college students in Semarang city. They feel familiar with the activity of telling their anxiety or problems to their friends in the virtual world. Although there is no solution, it is said to be "not-too-bad" for its cathartic capability. This type of communication for the counselee-counsellor services is favorably chosen because counselees can communicate without having to meet counsellors in person, and it's relationship is way more calming. The students as counselees will feel achieve a more comfortable and effective communication when using either e-mail or social media services.

The benefits that students will get by getting a cyber counseling services are the practical function that it can be easily accessed anywhere, and the flexibility of using it anytime, and anywhere (Gokhale \& Bhakare, 2011). Services in the form of e-mail are very personal and can be kept confidential, giving students the opportunity to reflect on themselves, as they feel comfortable in opening themselves to convey their feelings and thoughts (Mishna, Bogo \& Sawyer, 2015). Another researchers Lewis, Coursol, Bremer, \& Komarenko (2015) stated that communicating through cyber counseling can help students overcome meaninglessness (no life goals) and powerlessness (inability to achieve what is expected).

From the aforementioned description, the hypothesis set in this study is, therefore, an increase in students' performance in statistics after receiving cyber counseling services.

\section{Methods}

\subsection{Sample and data collection}

The participants are thirty students from the Faculty of Psychology in Soegijapranata Catholic University - Semarang City Indonesia, academic year of 2017/2018. The students are in their first semester, who are taking statistics class. The participants obtained below average grades (50) during their first four weeks. The average of participants' grades will be used as a pretest. The post test will be obtained by calculating the participants' test grades average, after having a four-month cyber counseling services.

\subsection{Procedure}

The researcher prepared a website providing the upload facility of statistics 
materials discussed in the class, e-mails, and chats. After getting the website ready, the researcher socialized and distributed the cyber counseling services as an aid for the students learning statistics. The lecturer would answer all questions raised by the students via e-mails and chats. Chat services are provided daily from 2 p.m. until 5 p.m., while e-mails would be given responses at a maximum of 48 hours. Students should log in using their names in the username field, and their student's class number in the password field. By doing this, lecturers are able to calculate the use of cyber counseling of every research subject.

\subsection{Data Analyses}

Quasi experiment with one group pretest posttest design was implemented. The participants were given the treatment of cyber counseling services. T-test analysis was performed when collecting statistics grades before giving cyber counseling services (pretest) and after giving cyber counselling services (posttest).

\section{Result and discussion}

The data results show significant differences in the results of students' statistics grades between prior and after receiving cyber counseling services treatment. After receiving the treatment, students got higher grades than before. The results of the data (t-test) show that $\mathrm{t}=34.372$, with $\mathrm{p}<0.01$, where $\mathrm{p}=0.0$. Therefore, the hypothesis stated before by the researcher, is accepted. Further calculation shows that the mean of research subjects before receiving treatment was 40.5. After receiving cyber counseling treatment, the mean of the research subject rate became 75.3. The data are presented in Table 1.

Table 1. Change of grades results in condition of before and after receiving treatment

\begin{tabular}{llll}
\hline No & Aspect & Status & Mean \\
\hline 1 & $\begin{array}{l}\text { Statistics } \\
\text { performance }\end{array}$ & $\begin{array}{l}\text { Before } \\
\text { treatment } \\
\text { After treatment }\end{array}$ & 40.5 \\
\hline
\end{tabular}

From the above result, the research hypothesis is, therefore, confirmed that research subjects obtained higher grades in statistics subject after receiving assistance from lecturers through cyber counseling services. The findings has also reinforced what has been found by Mishna, Bogo \& Sawyer
(2015) stated that the cyber counseling service gives students the opportunity to share their feelings and thoughts in learning statistics more openly, whenever and wherever without being afraid of receiving neglect from other students.

Rawson \& Maidment (2011) mentioned that cyber counseling service is one of several counseling strategis which is done virtually through internet connection as its media. Steele, Jacokes \& Stone (2014) furthermore added that cyber counseling service is providing professional counseling services between a counsellors with a counselee who are separated in terms of place, but connected via e-mail and chat.

Individuals born after 1980 grew up with rapid technological developments. This situation enabled them to network and communicate easily with anyone, anywhere in the world through the internet. This unique generation is called $\mathrm{N}$ generation (Networked generation). For this generation technology and communication over the internet really color their lives. So it is possible to provide cyber counseling assistance (Mishna, Bogo, \&Sawyer, 2015).

In the tertiary education, students aged between 18-23 years are experiencing transition phase from adolescence to early adulthood. The students life is colored by the academic bustle, social relationships with peers and adults around them that influence their strive to live as adults. Thus, during this phase, students are required to have commitments, to develop adult life values, and to solve problems creatively. For college students who are entering adulthood, such demands often lead to social alienation, and emotional tension. There come times that problems arised cannot be solved alone but require others to gain enlightenment to help solve the problems. (Andersen \& Svensson, 2013). Thus, the students are expected to be helped to feel comfortable while learning statistics subject so that they feel capable of understanding the materials presented by lecturers and obtain high grades. Help can be given in the form of counseling assistance of cyber counseling by listening to students' complaints. The counseling is done to trigger students to be interested in learning stastistics, in order to overcome the confusion in studying stastistics (Bianchini, 2011). By this way students' psychological well being can be 
increased which involves high self acceptance, high positive relationship with others, high autonomy, high environmental mastery, high purpose of life, and high personal growth. Weiss, Westerhof \& Bahlmeijer (2016).

Additional research result showed that based on the data collection, profiles of the research subject are mentioned as follows: nineteen female students (63.3\%), and eleven male students (36.7\%). Research subjects who take science major (IPA) in high school are counted to five students $(16.6 \%)$, social major (IPS) were fourteen students (46.7\%), and language major (Bahasa) students were eleven students $(36.7 \%)$. The data is presented in Table 2.

Table 2 . Profiles of research subject

\begin{tabular}{llll}
\hline No & Aspects & Frequency & Percentage \\
\hline 1 & Gender & 19 & 63.3 \\
& $\begin{array}{l}\text { Female } \\
\text { Male }\end{array}$ & 11 & 36.7 \\
2 & $\begin{array}{l}\text { Major } \\
\text { Science } \\
\text { (IPA) }\end{array}$ & 5 & 16.6 \\
& $\begin{array}{l}\text { Social } \\
\text { (IPS) } \\
\text { Language } \\
\text { (Bahasa) }\end{array}$ & 14 & 46.7 \\
\hline
\end{tabular}

The data results show that female students got lower grades in statistics course compared to male students, thus, the results are in accordance with Chen, Hsu \& Chen (2013). This result shows that female students need to be given more stimulations to seek for help more actively in order to get deeper understanding of statistics learning.

It is also found that the research subjects majoring in non-science (non-IPA) concentration experienced more difficulty in learning statistics compared to subjects majoring in science (IPA) concentration. This result is supported by the research results done by Macher, Paecter, Paousek, \& Ruggeri (2012), who stated that students majoring in science (IPA) concentration were more familiar and therefore got used to learning subjects dealing with exact sciences and numeric.

Lecturers gave opportunity for the students to get cyber counseling services as a daily treatment with the duration of 3 hours per day for 4 months. The average frequency of students using cyber counselling services was reported 80 times $(66,7 \%)$ out of the total 120 times. The data are presented in the Table 3.

Table 3. The average result of students using cyber counseling services

\begin{tabular}{lllc}
\hline No & Aspect & Frequency & Percentage \\
\hline 1 & Students & 80 & 66.7 \\
& using & & \\
cyber & & \\
& $\begin{array}{l}\text { counselling } \\
\text { services }\end{array}$ & & \\
\hline
\end{tabular}

In the future, it seems necessary to prepare a more attractive cyber counseling service to trigger frequency improvement of students using cyber counseling services.

\section{Conclusion}

As a conclusion, the experiment of using cyber counseling has been proven to improve students' statistics performance. Further psychology classroom activities such as the statistics class discussed in this research report are, therefore, expected make use of the cyber counseling services.

\section{References}

Anderson, A.J.W \& Svensson, T. (2013). Internet-Based Mental Healh Services in Norway and Sweden: Characteristics and Consequences. Journal Adm Policy Mental Health. 40, 145-153.doi: 10.1007/s10488-011-0388-2.

Bloom, J.W \& Walz, G.R. (2014). Cybercounseling \& Cyberlearning. An Encore, US: CAPS

Press.

Bianchini, J.A. (2011). How to Foster StudentStudent Learning of Science? The Student, The Teacher and The Subject Matter. Journal Cult Stud of Sci Educ 6, 871-882.doi:10.1007/s11422-011-9359$\mathrm{x}$.

Chen, B.H., Hsu, M.S \& Chen M.H. (2013). The Relationship between Learning Attitude and Anxiety in Accounting Classes: The Case of Hospitality Management University Students in Taiwan. Journal Qual Quant 47, 28152827. doi: 10.1007/s11135-012-9691-6. 
Corey, G. (2013). Theory and Practice of Counseling and Psychotherapy, USA: Brooks/Cole.

Gokhale, R \& Bhakare, S. (2011). New Learning Paradigms: The S-M-S Way and Student to Student Learning with Mobil Technology. International Journal of Aris \& Science. 4(8), 275283.

Gningue, S.M., Peach, R \& Schroder, B. (2013). Developing Effective Mathematics Teaching: Assessing Content and Pedagogical Knowledge, Student-Centered Teaching, and Student Engagement. The Matematics Enthusiast, ISSN 1551-3440, 10(3), 621-646.

Joel, E., \& Amanda, B.W. (2013). Smart Phone Applications in Clinical Practice. Journal of Mental Health Counseling. 35(4), 283-293.

Jung, I. (2011). The Dimensions of E-Learning Qulity: From The Learner's Perspective. Journal Education Tech Research Dev. 59, 445-464. doi: 10.1007/s11423-0109171-4.

Lewis, J., Coursol, D.H., Bremer, K.L \& Komarendo, O. (2015) Alienation Among College Students and Attitudes Toward Face-to-Face and Online Counseling: Implications for Student Learning. Journal of Cognitive Education and Psychology.14(1), 28-37.

Macher, D., Paechter, M \& Papousek, I \& Ruggeri, K. (2012). Statistics Anxiety, Trait Anxiety, Learning Behaviour, and Academic Performance. Journal Psychology Education. 27, 483498.doi:10.1007/s10212-011-0090-5.

Malik, S. (2015). Undergraduates' Statistics Anxiety: A Phenomenological Study. The Qualitative Report. 20 (2), 120-133.

Misha, F., Bogo, M \& Sawyer, J.K. (2015). Cyber Counseling: Illuminating Benefits and Challenges. Journal Clin Soc Work.
43, 169-178.doi:10.1007/s10615-0130470-1.

Nguyen, T.H., Newby, M \& Skordi, P.G. (2015). Development and Use of An Instrument to Measure Students' Perceptions of a Business Statistics Learning Environment in Higher Education. Journal Learning Environ Res. 18, 409-424.doi:10.1007/s10984015-9192-3.

Rawson, S \& Maidment, J. (2011). Email Counseling with Young People in Australia: A Research Report. Woman in Welfare Education 10, 14-28.

Ryff, C.D. (2014). Psychological Well Being Revisited: Advances in The Science and Practice of Eudaimonia. Journal of Psychoterapy and Psychosocial. 83(17), 10-28. doi: 10.1159/0003532632013-41405-003.

Steele, T.M., Jacokes, D.E. \& Stone, C.B (2012). An Examination of The Role of Online Technology in School Counseling. The American School Counselor Association 18, 125-135.

Tu, W \& Snyder, M.M. (2017). Developing Conceptual Understanding in A Statistics Course: Merrill's First Principles an Real Data at Work. Journal Education Tech Research Dev 65, 579595.

Vinluan, L.R. (2011). The Use of ICT in School Guidance: Attitudes and Practices of Guidance Counselors in Metro Manila, The Philippines. Journal Adv Counseling 33, 22-36.doi: 10.1007/s10447-010-9110-4.

Weiss, L.A., Westerhof, G.J \& Bahlmeijer. (2016). Can We Increase Psychological Well Being? The Effect Of Interventions On Psychological PWB: A Meta Analysis of Randomized Controlled Trial. Journal Pone 11 (6), 116. doi:10.13711.0158092 